\title{
Differential effects of dietary protein sources on postprandial low-grade inflammation after a single high fat meal in obese non-diabetic subjects
}

\author{
Jens Holmer-Jensen ${ }^{1 *}$, Toni Karhu² ${ }^{2}$ Lene S Mortensen ${ }^{1}$, Steen B Pedersen', Karl-Heinz Herzig ${ }^{2}$ and \\ Kjeld Hermansen ${ }^{1}$
}

\begin{abstract}
Background: Obesity is a state of chronic low-grade inflammation. Chronic low-grade inflammation is associated with the pathophysiology of both type-2 diabetes and atherosclerosis. Prevention or reduction of chronic lowgrade inflammation may be advantageous in relation to obesity related co-morbidity. In this study we investigated the acute effect of dietary protein sources on postprandial low-grade inflammatory markers after a high-fat meal in obese non-diabetic subjects.
\end{abstract}

Methods: We conducted a randomized, acute clinical intervention study in a crossover design. We supplemented a fat rich mixed meal with one of four dietary proteins - cod protein, whey isolate, gluten or casein. 11 obese nondiabetic subjects (age: 40-68, BMl: 30.3-42.0 kg/m2) participated and blood samples were drawn in the $4 \mathrm{~h}$ postprandial period. Adiponectin was estimated by ELISA methods and cytokines were analyzed by multiplex assay. Results: MCP-1 and CCL5/RANTES displayed significant postprandial dynamics. CCL5/RANTES initially increased after all meals, but overall CCL5/RANTES incremental area under the curve (iAUC) was significantly lower after the whey meal compared with the cod and casein meals $(P=0.0053)$. MCP-1 was initially suppressed after all protein meals. However, the iAUC was significantly higher after whey meal compared to the cod and gluten meals $(P=$ 0.04).

Conclusion: We have demonstrated acute differential effects on postprandial low grade inflammation of four dietary proteins in obese non-diabetic subjects. CCL5/RANTES initially increased after all meals but the smallest overall postprandial increase was observed after the whey meal. MCP-1 was initially suppressed after all 4 protein meals and the whey meal caused the smallest overall postprandial suppression.

Trial Registration: ClinicalTrials.gov ID: NCT00863564

Keywords: obesity, metabolic syndrome, dietary protein, nutrition, inflammation, cytokines, postprandial period

\section{Background}

The global incidence of obesity is escalating at epidemic proportions. The obesity related co-morbidities include increased incidence of the metabolic syndrome, type-2 diabetes (T2DM), hypertension, dyslipidaemia and chronic low-grade inflammation [1,2].

Interestingly, Hotamisligil et al [3] in 1993 suggested that chronic low-grade inflammation plays a role in the

\footnotetext{
* Correspondence: holmer-jensen@ki.au.dk

'Department of Endocrinology and Metabolism MEA, Aarhus University Hospital, Aarhus, Denmark

Full list of author information is available at the end of the article
}

pathophysiology of obesity in general and of insulin resistance in particular. This has subsequently been supported by the demonstration of a correlation between circulating levels of inflammatory markers and both T2DM [4] and atherosclerosis in humans [5-8].

White adipose tissue (WAT) is an important endocrine organ that secretes molecules, referred to as adipokines [9]. The chronic low-grade inflammation of obesity is characterized by increased concentrations of circulating inflammatory adipokines and cytokines [10-13]. Importantly, the inflammatory and metabolic pathways are linked. WAT is infiltrated with macrophages in response

\section{Biomed Central}


to adipocyte hypertrophy and the associated increase in monocyte chemotactic protein-1 (MCP-1) expression $[14,15]$. Increased circulating concentrations of MCP-1 are in humans predictive of both diabetes risk independently of other traditional risk factors [16] and atherosclerosis $[17,18]$. Furthermore, differentiation of monocytes into macrophages starts in plasma, when monocytes are activated in response to postprandial triglyceride rich lipoproteins $[19,20]$ and free fatty acids [21]. While MCP-1 is now regarded as a key inflammatory marker, CC chemokine ligand-5 (CCL5/RANTES) has in recent years emerged as a potentially therapeutic target in the prevention of atherosclerosis [22,23]. The interaction between CCL5/RANTES and monocytes facilitates the adherence and transmigration of monocytes through the arterial wall [22] initiating the atherosclerotic process. CCL5/RANTES antagonisms have been demonstrated to reduce atherosclerotic lesions in mice [24]. Furthermore, CCL5/RANTES is up-regulated in WAT of obese compared to lean subjects [25] facilitating macrophage infiltration of adipose tissue.

Though, the impact of dietary protein on postprandial inflammation has not been thoroughly elucidated, the impact of diet in general on low-grade inflammation has been demonstrated (reviewed in [26]). Thus, a positive correlation to postprandial inflammation has been demonstrated for total energy intake in healthy men $[27,28]$ and a diet rich in saturated fat in overweight subjects [29]. Moreover dyslipidaemia characteristically for obesity, i.e. hypertriglyceridaemia, elevated apolipoprotein (Apo) B and small, dense low-density lipoproteins (LDL) has been positively correlated to low-grade inflammation in abdominally obese subjects with and without the metabolic syndrome [30]. The composition of meal fatty acids play an important role for low-grade inflammation in humans i.e. n-3 polyunsaturated fatty acids (PUFA) being anti-inflammatory while n-6 PUFA and saturated fatty acids appear to be pro-inflammatory [31-33]. The impact of dietary carbohydrate on postprandial inflammation is controversial [26,34].

Less is known about the influence of dietary protein on postprandial inflammation. Arya et al [35] demonstrated that meat with high fat content is more pro-inflammatory compared to lean meat in healthy subjects. Moreover, an inverse relationship has been demonstrated between dairy product consumption and low-grade inflammation in healthy subjects [36] and obese subjects [37].

We hypothesize that dietary protein sources may exert a differential impact on acute postprandial low-grade inflammation. In the present study we focused on the two inflammatory markers MCP-1 and CCL5/RANTES. As cod protein, gluten, casein and whey protein have been demonstrated to elicit differential postprandial lipid, glucose and hormone responses in healthy [38], overweight
[39] and type-2 diabetic subjects [40] these four protein sources originating from fish, crops and milk may be suitable for assessing the impact of dietary protein on postprandial low-grade inflammation. The differential impact of the four protein sources on postprandial triglycerides and insulin may particularly reveal correlated differential responses on postprandial low-grade inflammation.

\section{Subjects and methods}

11 obese Caucasian subjects ( 8 postmenopausal women and 3 men) were recruited after advertising in local newspapers. All subjects had a body mass index (BMI) above 30 and all subjects were non-diabetics according to fasting plasma glucose $<7.0 \mathrm{mmol} / \mathrm{l}$. Subjects with impaired fasting glucose were subjected to an oral glucose tolerance test and were excluded if the $2 \mathrm{~h}$ plasma glucose level was $\geq 11.1 \mathrm{mmol} / \mathrm{l}$. No participant took medication with impact on lipids, inflammation, immune system or insulin sensitivity and all participants were non-smokers. No change in concomitant medication was allowed during the trial. Subject characteristics are shown in Table 1. All subjects gave written informed consent and the study was approved by The Committees on Biomedical Research Ethics for the Central Region of Denmark. This study was registered at clinicaltrials.gov (ID: NCT00863564).

\section{Study design}

We performed a nested randomized, acute clinical intervention study. All subjects ingested four different meals on four different days with a washout period of two weeks between meals. Each subject was randomized to one of four meal sequences based on a Latin square design. Before each test day the subjects were given and consumed a standard diet with the following energy distribution: $56 \%$ energy from carbohydrate, $24 \%$ energy from fat and $20 \%$ energy from protein. The energy content was 7

\begin{tabular}{|c|c|}
\hline Age (yr) & $55.2 \pm 9.4(40-68)$ \\
\hline Weight (kg) & $100.9 \pm 13.8(79.0-120.9)$ \\
\hline $\mathrm{BMI}\left(\mathrm{kg} / \mathrm{m}^{2}\right)$ & $33.9 \pm 3.4(30.3-42.0)$ \\
\hline Waist (cm) & $111.4 \pm 6.8(102-121)$ \\
\hline $0^{n}$ & $118.7 \pm 2.1(117-121)$ \\
\hline \& & $108.6 \pm 5.7(102-117)$ \\
\hline Waist-to-hip ratio & $0.92 \pm 0.07(0.83-1.08)$ \\
\hline $0^{n}$ & $1.01 \pm 0.06(0.98-1.08)$ \\
\hline ㅇ & $0.89 \pm 0.03(0.83-0.92)$ \\
\hline $\mathrm{HbA1c}(\%)$ & $5.8 \pm 0.4(5.3-6.5)$ \\
\hline HOMA2 (IR) & $1.3 \pm 0.5(0.3-2.0)$ \\
\hline Fasting plasma glucose $(\mathrm{mmol} / \mathrm{l})$ & $5.9 \pm 0.4(5.3-6.6)$ \\
\hline Fasting plasma triglyceride $(\mathrm{mmol} / \mathrm{l})$ & $2.0 \pm 0.8(0.7-3.1)$ \\
\hline
\end{tabular}

${ }^{1}$ All values are means \pm SD; range in parentheses. 
$000 \mathrm{~kJ}$ for women and $9000 \mathrm{~kJ}$ for men. All subjects were asked to refrain from alcohol consumption and exercise in the $24 \mathrm{~h}$ preceding the test day. In the morning after a $12 \mathrm{~h}$ fasting period a catheter was inserted into an antecubital vein. After $15 \mathrm{~min}$ of rest baseline samples were drawn. The test meal was served and ingested within $20 \mathrm{~min}$ and blood samples for inflammatory markers were drawn in the $4 \mathrm{~h}$ postprandial period. The subjects were allowed to drink tap water ad libitum. Plasma was separated immediately by centrifugation at $2000 \times \mathrm{g}$ for $20 \mathrm{~min}$ at $4^{\circ} \mathrm{C}$. Plasma samples were stored at $-80^{\circ} \mathrm{C}$ until analyzed.

\section{Test meals}

All subjects consumed in random order four fat rich test meals containing 4971 - $4986 \mathrm{KJ}$ with $19 \mathrm{E} \%$ carbohydrate, $66 \mathrm{E} \%$ fat and $15 \mathrm{E} \%$ protein, respectively. All test meals consisted of an energy free soup with an added $100 \mathrm{~g}$ of butter (Lurpak; Arla Foods amba, Viby J, Denmark) corresponding to $80 \mathrm{~g}$ of fat ( $68 \%$ of energy as saturated fat). 45 $\mathrm{g}$ of carbohydrate was added as white wheat bread (Läntmann Schulstad A/S, Hvidovre, Denmark) and $45 \mathrm{~g}$ of a protein preparation was added or served with the meal. The protein sources were cod, whey isolate, gluten and casein. The $45 \mathrm{~g}$ of cod protein (cod meal) corresponded to $285 \mathrm{~g}$ of minced cod filet (Coop torskefilet; Royal Greenland A/S, Aalborg, Denmark). This was added to the soup before heating. The spray dried whey isolate (whey meal) (Lacprodan DI-9224; kindly provided by Arla Foods Ingredients amb, Viby J, Denmark) was dissolved in $200 \mathrm{ml}$ water and served with the meal. Gluten (gluten meal) (Gluvital 21000; kindly provided by Cerestar Scandinavia $\mathrm{A} / \mathrm{S}$, Charlottenlund, Denmark) was mixed into the soup before heating. Casein (casein meal) was applied as spray dried calcium caseinate (Miprodan 40; kindly provided by Arla Foods Ingredients amba, Viby J, Denmark). Half of the casein was dissolved in water and the other half was added to the soup before heating. To make the soup more palatable we added $25 \mathrm{~g}$ of sliced raw leek, $1 \mathrm{~g}$ of curry and $1 / 2$ dice of chicken bouillon. The soup had a serving temperature of $65^{\circ} \mathrm{C}$. The total amount of water in each meal was $675 \mathrm{ml}$ and the total volume of each meal did not differ.

\section{Blood analyses}

Adiponectin was measured using the B-Bridge Int. human adiponectin enzyme-linked immunosorbant assay (ELISA) kit (Cat\# K1001-1), (CV: 3.2\%). All other inflammatory markers were assessed using a fixed Bio-Plex Pro Human Cytokine 27-plex array (Cat\# M50-0KCAF0Y) according to manufacturer's instructions, (CV: 5-15\%) as described previously [33,41]. Plasma samples were diluted 1:2 and incubated with anti-cytokine antibody-coupled beads for
$30 \mathrm{~min}$ at room temperature. Beads were then incubated with biotinylated detection antibodies for $30 \mathrm{~min}$, before incubation with Streptavidin-phycoerythrin for $30 \mathrm{~min}$. Following each incubation step, complexes were washed 3 times in wash buffer using the Bio-Plex Pro Wash Station. Finally, complexes were resuspended in $125 \mu$ l of assay buffer, and beads were counted on the Bio-Plex 200 system (Bio-Rad). Duplicates were performed. Mean fluorescence intensity was analyzed and data was given as $\mathrm{pg} / \mathrm{ml}$. The 27-plex array included the following cytokines: Interleukine (IL)-1b, IL-1 receptor antagonist (IL-1ra), IL-2, IL-4, IL-5, IL-6, IL-7, IL-8, IL-9, IL-10, IL-12 (p70), IL-13, IL-15, IL-17A, basic fibroblast growth factor (basic FGF), eotaxin, granulocyte colony stimulating factor (G-CSF), granulocyte macrophage colony stimulating factor (GMCSF), interferon- $\gamma($ IFN- $\gamma)$, IFN- $\gamma$ induced protein $10 \mathrm{kDa}$ (IP-10), MCP-1, macrophage inflammatory protein-1 $\alpha$ (MIP-1 $\alpha$ ), MIP-1 $\beta$, platelet derived growth factor BB (PDGF-BB), CCL5/RANTES, Tumor necrosis factor- $\alpha$ (TNF- $\alpha$ ), vascular endothelial growth factor (VEGF).

\section{Statistical analysis and calculations}

Comparisons were based on a mixed effects model [42] (STATA/IC 10.1) using treatment group as fixed variable and participant ID as random variable. All estimates were adjusted for treatment order, baseline values, gender and waist-to-hip ratio. F-test or Wald test were applied as appropriate. A $P$ value $<0.05$ was considered statistically significant. Any statistical significant main effect of meal was followed up by Tukey's post hoc correction for pair wise comparison. Whenever data was not normally distributed, a log transformation was performed and the statistical analysis was carried out on the normal distributed log data. Data was given as net incremental area under the curve (iAUC) 0-240 min. Net iAUC was calculated using trapezoidal rule. Data was given as means \pm SD in tables and as means \pm SE in graphs unless otherwise stated. When statistical analyses were performed on log transformed data, results were given as medians with interquartile ranges. Any sample with a value below detection limit was omitted from the statistical analyses. No statistical analyses were performed on cytokines with more than $9 \%$ of samples below detection limit: IL-1b, IL-2, IL-4, IL-5, IL-6, IL-7, IL-8, IL-9, IL-10, IL-12 (p70), IL-13, IL-15, IL-17A, basic FGF, GM-CSF, MIP- $1 \alpha$ and TNF- $\alpha$.

\section{Results}

The 11 obese non-diabetic subjects completed the four test meals according to protocol. No significant differences in fasting cytokines concentrations were found (Table 2). No significant weight changes were found between first $(100.5 \mathrm{~kg})$ and last $(100.4 \mathrm{~kg})$ test day. 
Table 2 Fasting concentrations and net incremental areas under the curve after 240 min (net iAUC 0-240 min) ${ }^{1}$ for inflammatory markers, insulin and triglycerides in 11 (8 women and 3 men) obese non-diabetic subjects in response to the four test-meals

\begin{tabular}{|c|c|c|c|c|}
\hline & Cod & Whey & Gluten & Casein \\
\hline \multicolumn{5}{|l|}{$\overline{\mathrm{MCP}-1}$} \\
\hline Fasting & $22 \pm 11$ & $21 \pm 7$ & $23 \pm 12$ & $21 \pm 11$ \\
\hline iAUC 0-240 min (pg/ml.240 min) & $-826 \pm 1255 x$ & $-77 \pm 1092 y$ & $-943 \pm 925 x$ & $-469 \pm 757 x y$ \\
\hline \multicolumn{5}{|l|}{ CCL5 } \\
\hline Fasting & $340 \pm 238$ & $490 \pm 396$ & $490 \pm 321$ & $409 \pm 297$ \\
\hline iAUC 0-240 min (pg/ml.240 min) & $50764 \pm 58218 x$ & $-18510 \pm 81999 y$ & $11235 \pm 55$ 558yz & $44488 \pm 37862 x z$ \\
\hline \multicolumn{5}{|l|}{ IL-1ra } \\
\hline Fasting & $68 \pm 18$ & $79 \pm 39$ & $76 \pm 34$ & $66 \pm 24$ \\
\hline iAUC 0-240 min (pg/ml.240 min) & $743 \pm 2871$ & $-1972 \pm 4005$ & $-1454 \pm 5068$ & $2173 \pm 4320$ \\
\hline \multicolumn{5}{|l|}{ PDGF-bb1 } \\
\hline Fasting & $40 \pm 41$ & $161 \pm 260$ & $65 \pm 78$ & $110 \pm 232$ \\
\hline iAUC 0-240 min (pg/ml.240 min) & 11837 (6 285 - 20 952) & 4303 (2 $102-6$ 995) & $6660(4851-10742)$ & $8604(6348-10435)$ \\
\hline \multicolumn{5}{|l|}{ IFN-g } \\
\hline Fasting & $25 \pm 12$ & $28 \pm 25$ & $30 \pm 21$ & $28 \pm 24$ \\
\hline iAUC 0-240 min (pg/ml.240 min) & $865 \pm 1610$ & $-1300 \pm 3747$ & $-791 \pm 2622$ & $397 \pm 2614$ \\
\hline \multicolumn{5}{|l|}{ Adiponectin } \\
\hline Fasting & $1.5 \pm 0.5$ & $1.5 \pm 0.6$ & $1.5 \pm 0.6$ & $1.5 \pm 0.5$ \\
\hline iAUC 0-240 min ( $\mu \mathrm{g} / \mathrm{ml} \cdot 240 \mathrm{~min})$ & $-7.7 \pm 48$ & $-8.5 \pm 49$ & $6.3 \pm 38$ & $-6.9 \pm 36$ \\
\hline \multicolumn{5}{|l|}{ Eotaxin } \\
\hline Fasting & $52 \pm 12$ & $53 \pm 14$ & $51 \pm 14$ & $49 \pm 16$ \\
\hline iAUC 0-240 min (pg/ml.240 min) & $-45 \pm 819$ & $601 \pm 2237$ & $-64 \pm 686$ & $983 \pm 1039$ \\
\hline \multicolumn{5}{|l|}{ G-CSF } \\
\hline Fasting & $11 \pm 3$ & $12 \pm 6$ & $11 \pm 4$ & $12 \pm 7$ \\
\hline iAUC 0-240 min (pg/ml.240 min) & $23 \pm 719$ & $-420 \pm 1242$ & $-114 \pm 685$ & $-194 \pm 955$ \\
\hline \multicolumn{5}{|l|}{$\mid \mathrm{P}-10$} \\
\hline Fasting & $579 \pm 166$ & $558 \pm 109$ & $588 \pm 226$ & $542 \pm 142$ \\
\hline iAUC 0-240 min (pg/ml.240 min) & $-2343 \pm 24198$ & $-10371 \pm 19737$ & $-3403 \pm 21448$ & $-5159 \pm 10121$ \\
\hline \multicolumn{5}{|l|}{ MIP-1b } \\
\hline Fasting & $45 \pm 16$ & $46 \pm 16$ & $44 \pm 14$ & $43 \pm 15$ \\
\hline iAUC 0-240 min (pg/ml.240 min) & $-908 \pm 1248$ & $-331 \pm 1411$ & $-302 \pm 534$ & $-219 \pm 428$ \\
\hline \multicolumn{5}{|l|}{ VEGF } \\
\hline Fasting & $7 \pm 3$ & $10 \pm 6$ & $7 \pm 3$ & $8 \pm 4$ \\
\hline iAUC 0-240 min (pg/ml.240 min) & $693 \pm 921$ & $270 \pm 1058$ & $233 \pm 448$ & $317 \pm 419$ \\
\hline \multicolumn{5}{|l|}{ Insulin } \\
\hline Fasting & $65 \pm 28$ & $63 \pm 33$ & $66 \pm 31$ & $62 \pm 32$ \\
\hline iAUC 0-240 min (pmol//.240 min) & $41158 \pm 11003 x$ & $73693 \pm 28022 y$ & $38738 \pm 10691 x$ & $50978 \pm 21477 x$ \\
\hline \multicolumn{5}{|l|}{ Triglycerides } \\
\hline Fasting & $2.0 \pm 1.0$ & $1.8 \pm 0.8$ & $1.9 \pm 0.7$ & $1.8 \pm 0.9$ \\
\hline iAUC 0-240 $\mathrm{min}(\mathrm{mmol} / / \cdot 240 \mathrm{~min})$ & $138 \pm 108$ & $122 \pm 95$ & $132 \pm 95$ & $127 \pm 94$ \\
\hline
\end{tabular}

${ }^{1}$ All values are means \pm SDs (normal distributions; mixed-effects model, Tukey's post hoc correction) or medians with interquartile ranges in parentheses (skewed distribution; mixed-effects model on normal distributed log-transformed data, Tukey's post hoc correction). Meals: energy-free soup plus $100 \mathrm{~g}$ butter and $45 \mathrm{~g}$ carbohydrate consumed with either $45 \mathrm{~g}$ cod, $45 \mathrm{~g}$ whey isolate, $45 \mathrm{~g}$ gluten or $45 \mathrm{~g}$ casein. MCP-1: monocyte chemotactic protein-1; CCL5: Chemokine ligand 5; IL-1 ra: interleukin 1 receptor-antagonist; PDGF-bb1: platelet derived growth factor BB; IFN-g: interferon-gamma; G-CSF: granulocyte colony-stimulating factor; IP10: interferon-gamma induced protein $10 \mathrm{kDa}$; MIP-1b: macrophage inflammatory protein 1b; VEGF: vascular endothelial growth factor. Values in a row with different superscript letters are significantly different, $P<0.05$.

\section{CCL5/RANTES}

The plasma concentrations of CCL5/RANTES increased for all meals at $30 \mathrm{~min}$ (Figure 1). The average increment at 30 min was $86 \%$. Towards the end of the observation period CCL5/RANTES concentrations decreased towards baseline for all meals. At $240 \mathrm{~min}$ CCL5/RANTES concentration after cod-meal was 52\% above baseline whereas CCL5/RANTES concentration 


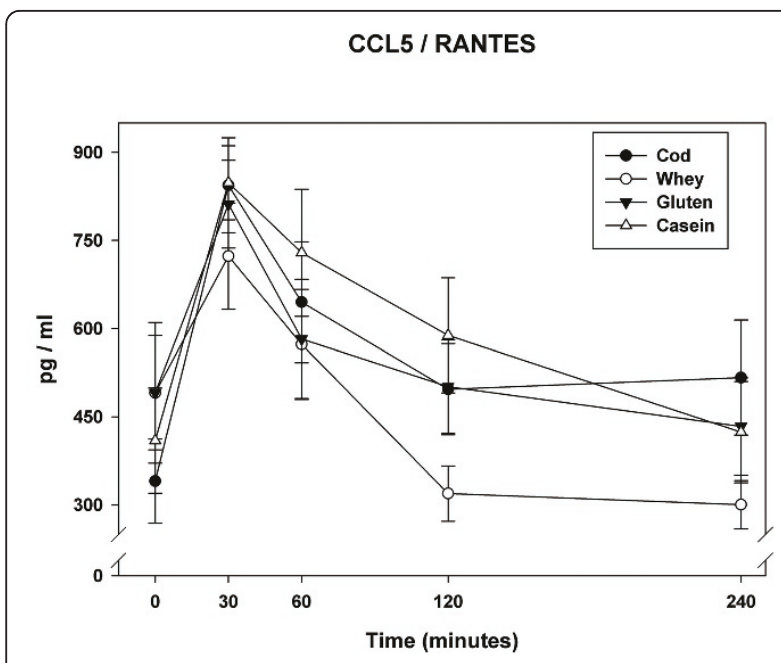

Figure 1 The plot show mean (+SEM) responses for CCL5/ RANTES in plasma in the $4 \mathrm{~h}$ postprandial period after the four meals consumed by 11 obese non-diabetic subjects. Meals consisted of an energy-free soup plus $80 \mathrm{~g}$ fat (from butter) and $45 \mathrm{~g}$ carbohydrate consumed with either $45 \mathrm{~g}$ cod protein, $45 \mathrm{~g}$ whey protein, $45 \mathrm{~g}$ gluten or $45 \mathrm{~g}$ casein.

after whey-meal was $39 \%$ below baseline. We found a statistically significant main effect of meal $(P=0.0053)$. The iAUC-240 min was lower after whey-meal compared to cod meal and casein meal. The iAUC-240 min was also lower after gluten meal compared to cod meal (Table 2). Post hoc analyses did not demonstrate differences between meals in CCL5/RANTES iAUC-60 min $(P=0.55)$. However, a negative correlation was demonstrated between insulin iAUC-240 min and CCL5/ RANTES iAUC-240 $\min (r=-0.33 ; P=0.04)$. No post hoc correlation could be demonstrated between triglycerides and MCP-1 (data not presented).

\section{MCP-1}

MCP-1 plasma levels decreased for all meals in the first $30 \mathrm{~min}$ (Figure 2). The mean decrement at $30 \mathrm{~min}$ was $17 \%$. Towards the end of the observation period MCP-1 levels after whey-meal reached baseline whereas MCP-1 concentrations only slightly increased but remained below baseline for the three other meals. We found a statistically significant main effect of meal $(P=0.040)$. The overall net suppression of MCP-1 was smaller for whey-meal compared to cod-meal and gluten-meal (Table 2). Post hoc analyses did not demonstrate differences between meals in MCP-1 iAUC-60 min $(P=$ 0.38 ). However, a post hoc correlation analysis revealed a positive correlation between insulin iAUC-240 min and MCP-1 iAUC-240 $\min (r=0.39 ; P=0.01)$. No post hoc correlation could be demonstrated between triglycerides and MCP-1 (data not presented).

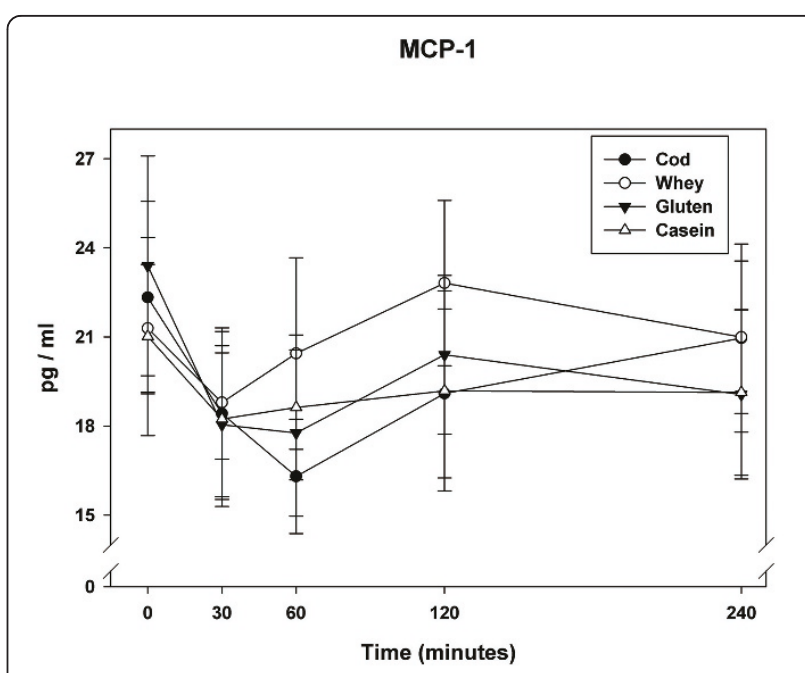

Figure 2 The plot show mean (+SEM) responses for MCP-1 in plasma in the $4 \mathrm{~h}$ postprandial period after the four meals consumed by 11 obese non-diabetic subjects. Meals consisted of an energy-free soup plus $80 \mathrm{~g}$ fat (from butter) and $45 \mathrm{~g}$ carbohydrate consumed with either $45 \mathrm{~g}$ cod protein, $45 \mathrm{~g}$ whey protein, $45 \mathrm{~g}$ gluten or $45 \mathrm{~g}$ casein.

\section{Other cytokines}

No significant differences between meals were observed for IFN- $\gamma$, adiponectin, eotaxin, G-CSF, IP-10, MIP-1 $\beta$, PDGF-BB, IL-1ra and VEGF, respectively (Table 2).

\section{Discussion}

We have demonstrated acute differential effects of dietary protein sources on postprandial low-grade inflammation after a high-fat meal in obese non-diabetic subjects. Of particular interest we observed that MCP-1 and CCL5/ RANTES displayed acute postprandial responses to the test meals. MCP-1 was initially suppressed and CCL5/ RANTES initially increased after consumption of the test meals. For both cytokines no significant differences between meals were evident at peak values after $60 \mathrm{~min}$. However, whey-meal was associated with a different overall response after 240 min compared to the other protein meals. MCP-1 was suppressed to a smaller extent after whey-meal compared to cod-meal and gluten-meal. CCL5/RANTES iAUC-240 min was smaller after the whey-meal compared to the other meals - in particular compared to cod-meal and casein-meal.

Several studies have demonstrated postprandial adherence of Apo B to monocytes and activation of monocytes in response to an oral fat loading test in healthy subjects $[19,20]$. The activation of monocytes is important for the endothelial adhesion of monocytes and subsequent transmigration across the endothelial wall where the monocytes differentiate into macrophages [43]. However, this process is further enhanced when oxidized LDL and chylomicron remnant particles are taken up by residing macrophages 
inside the vessel wall. These macrophages activate the endothelium to produce MCP-1 which in mice resulted in further localized recruitment and tissue infiltration of monocytes [44]. In the endothelial wall the phagocytosis of oxidized lipoproteins by macrophages precedes the development of atherosclerotic plaques. Consequently any means to reduce endothelial adhesion of monocytes may reduce the progression of atherosclerotic plaques.

The CCL5/RANTES response was significantly smaller after whey meal compared to the cod and casein meals. Krohn et al [45] demonstrated reduction of neointimal thickening and macrophage infiltration in CCL5/RANTES knock-out mice. These findings are consistent with the CCL5/RANTES antagonist study of Braunersreuther et al [46] who also demonstrated that deficiency of the CCL5/ RANTES receptor protects Apo E -/- mice from diet induced atherosclerosis [47]. The finding of up-regulated CCL5/RANTES in human atherosclerotic plaques [48] corroborates with the association demonstrated between CCL5/RANTES and unstable angina pectoris [49] and myocardial infarction [50]. While CCL5/RANTES is thought to be crucial to monocyte recruitment during development of atherosclerosis [51] high density lipoprotein may partly cause its cardioprotective effect by reducing circulating levels of CCL5/RANTES [52]. Furthermore, high levels of CCL5/RANTES had a positive correlation to the development of T2DM in humans [53].

In the present study cod protein and gluten induced significantly lower concentrations of MCP-1 compared to whey protein. The mechanism of action is not known. However, in the cod-meal the total quantity of n-3 fatty acids was $752 \mathrm{mg}$, which may contribute to the antiinflammatory effects via interaction with the pro-inflammatory transcription factor i.e. nuclear factor kappa beta $(\mathrm{NF}-\kappa \mathrm{B})[54,55]$. However, since gluten does not contain any $\mathrm{n}-3$ fatty acids it may be speculated that cod and gluten do not share particular MCP-1 lowering properties. MCP-1 may be higher after whey meal due to whey specific properties e.g. higher insulin response as discussed later.

Research on the immunomodulatory properties of milk proteins has traditionally been focusing on the antimicrobial effects of T-cells, macrophages and the innate immune response [56]. The availability of immunomodulatory peptides is not solely depending on the dietary composition but also varies depending on the specific enzymatic digestion of milk components in the intestinal tractus [57]. Aihara et al [58] demonstrated that the casein and whey derived tri-peptide valyl-prolyl-proline modulates monocyte adhesion to inflamed endothelia in vitro via attenuation of the pro-inflammatory c-Jun $\mathrm{N}$ terminal kinases (JNK) pathway. Interestingly, the casein subunit " $\alpha$ s1" is expressed by monocytes in vitro [59] promoting a pro-inflammatory cytokine response.
Furthermore, Zemel et al [36] demonstrated reduced levels of MCP-1 after a dairy rich diet but not after a soy rich diet in a 28 day intervention period. These observations support that circulating peptides from a dairy product rich diet may at least in part be responsible for the differential cytokine responses observed after the four meals in the present study.

Whey protein reduces postprandial lipaemia more than cod, gluten and casein $[39,40]$. However, we could not demonstrate any correlation between postprandial lipaemia and the inflammatory markers.

Euglycemic hyperinsulineamia has been found to inhibit NF- $\kappa$ B and reduce concentrations of MCP-1 in obese subjects after $2 \mathrm{~h}$ and $4 \mathrm{~h}$ of insulin infusion [60,61]. As whey protein is more insulinotropic than cod protein, gluten and casein this mechanism would imply a larger suppression of MCP-1 after the whey meal compared to the other meals. However, we have demonstrated a positive correlation between postprandial insulin and MCP-1 as well as a negative correlation between postprandial insulin and CCL5/RANTES. This is in accordance with our findings that the MCP-1 iAUC-240 min for the whey meal was larger compared to the other meals and that the CCL5/RANTES iAUC-240 min was smaller after whey meal. Other studies have demonstrated anti-inflammatory properties of insulin infusion on both MCP-1 and CCL5/RANTES [62]. We cannot explain the opposing effects of whey meal on MCP-1 and CCL5/RANTES in our study.

\section{Conclusion}

MCP-1 and CCL5/RANTES are risk markers closely associated to obesity related risk factors, i.e. dyslipidaemia and insulin resistance. Long-term studies are needed to establish the potentially clinical effect of the impact of dietary protein on postprandial low-grade inflammation. In the present study we demonstrated an inverse relationship between concentrations of postprandial MCP-1 and CCL5/RANTES after the cod, whey isolate, gluten and casein meals.

This study is an exploratory pilot study indicating differential effects of dietary protein sources on postprandial inflammatory cytokines. Inclusion of different protein rich foods may enhance or diminish the inflammatory properties of a given diet. As circulating concentrations of MCP-1 and CCL5/RANTES are profoundly affected in the postprandial period, future research on postprandial low-grade inflammation should include these key inflammatory markers.

\section{List of abbreviations}

Apo: apo protein; BMI: body mass index; CCL5: CC chemokine ligand-5; ELISA: enzyme-linked immunosorbent assay; FGF: fibroblast growth factor; GCSF: granulocyte colony stimulating factor; GM-CSF: granulocyte 
macrophage colony stimulating factor; iAUC: incremental area under the

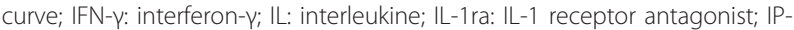
10: interferon- $\gamma$ induced protein $10 \mathrm{kDa}$; JNK: c-Jun N-terminal kinases; LDL: low density lipoproteins; MCP-1: monocyte chemotactic protein-1; MIP-1a: macrophage inflammatory protein-1a; NF-kB: nuclear factor kappa beta; PDGF-BB: platelet derived growth factor BB; PUFA: poly unsaturated fatty acids; RANTES: regulated upon activation; normal T-cell expressed; and secreted; T2DM: type 2 diabetes; TNF-a: tumor necrosis factor-a; VEGF: vascular endothelial growth factor; WAT: white adipose tissue.

\section{Acknowledgements}

This work is carried out as a part of the research program of the Danish Obesity Research Centre (DanORC, see http://www.danorc.dk) and is supported by Nordic Centre of Excellence (NCoE) programme (Systems biology in controlled dietary interventions and cohort studies - SYSDIET, P No., 070014).

\section{Author details}

'Department of Endocrinology and Metabolism MEA, Aarhus University Hospital, Aarhus, Denmark. ${ }^{2}$ Institute of Biomedicine and Biocenter of Oulu Faculty of Medicine, Finland.

\section{Authors' contributions}

$\mathrm{JHJ}, \mathrm{TK}, \mathrm{KHH}$ and $\mathrm{KH}$ designed the study. JHJ and LSM recruited subjects and collected the data. SBP, TK and KHH performed the blood analyses. JHJ performed the data analysis. JHJ was responsible for drafting the manuscript; $\mathrm{KH}$ assisted with the editing of the manuscript. JHJ had primary responsibility for final content. All authors participated in the discussion of the results and commented on the manuscript. All authors read and approved the final manuscript.

\section{Conflicts of interests}

The authors declare that they have no competing interests.

Received: 27 June 2011 Accepted: 19 October 2011 Published: 19 October 2011

\section{References}

1. Biro FM, Wien M: Childhood obesity and adult morbidities. Am J Clin Nutr 2010, 91:1499S-1505S.

2. Schelbert KB: Comorbidities of obesity. Prim Care 2009, 36:271-285,

3. Hotamisligil GS, Shargill NS, Spiegelman BM: Adipose expression of tumor necrosis factor-alpha: direct role in obesity-linked insulin resistance. Science 1993, 259:87-91.

4. Pradhan AD, Manson JE, Rifai N, Buring JE, Ridker PM: C-reactive protein, interleukin 6, and risk of developing type 2 diabetes mellitus. JAMA 2001, 286:327-334.

5. Ridker PM, Buring JE, Cook NR, Rifai N: C-reactive protein, the metabolic syndrome, and risk of incident cardiovascular events: an 8-year followup of 14719 initially healthy American women. Circulation 2003, 107:391-397.

6. Libby P, Ridker PM, Hansson GK, Leducq Transatlantic Network on Atherothrombosis: Inflammation in atherosclerosis: from pathophysiology to practice. J Am Coll Cardiol 2009, 54:2129-2138.

7. Danesh J, Wheeler JG, Hirschfield GM, Eda S, Eiriksdottir G, Rumley A, Lowe GD, Pepys MB, Gudnason V: C-reactive protein and other circulating markers of inflammation in the prediction of coronary heart disease. $N$ Engl J Med 2004, 350:1387-1397.

8. Danesh J, Kaptoge S, Mann AG, Sarwar N, Wood A, Angleman SB, Wensley F, Higgins JP, Lennon L, Eiriksdottir G, Rumley A, Whincup PH, Lowe GD, Gudnason V: Long-Term Interleukin-6 Levels and Subsequent Risk of Coronary Heart Disease: Two New Prospective Studies and a Systematic Review. PLoS Med 2008, 5:e78.

9. Wang P, Mariman E, Renes J, Keijer J: The secretory function of adipocytes in the physiology of white adipose tissue. J Cell Physiol 2008, 216:3-13.

10. Yudkin JS, Stehouwer CD, Emeis JJ, Coppack SW: C-reactive protein in healthy subjects: associations with obesity, insulin resistance, and endothelial dysfunction: a potential role for cytokines originating from adipose tissue? Arterioscler Thromb Vasc Biol 1999, 19:972-978.

11. Festa A, D'Agostino R Jr, Williams K, Karter AJ, Mayer-Davis EJ, Tracy RP, Haffner SM: The relation of body fat mass and distribution to markers of chronic inflammation. Int J Obes Relat Metab Disord 2001, 25:1407-1415.
12. Park HS, Park JY, Yu R: Relationship of obesity and visceral adiposity with serum concentrations of CRP, TNF-alpha and IL-6. Diabetes Res Clin Pract 2005, 69:29-35.

13. Fain JN: Release of inflammatory mediators by human adipose tissue is enhanced in obesity and primarily by the nonfat cells: a review. Mediators Inflamm 2010, 2010:513948.

14. Ito A, Suganami T, Miyamoto Y, Yoshimasa Y, Takeya M, Kamei Y, Ogawa Y: Role of MAPK phosphatase- 1 in the induction of monocyte chemoattractant protein-1 during the course of adipocyte hypertrophy. J Biol Chem 2007, 282:25445-25452.

15. Sell $\mathrm{H}$, Eckel J: Monocyte chemotactic protein-1 and its role in insulin resistance. Curr Opin Lipidol 2007, 18:258-262.

16. Herder C, Baumert J, Thorand B, Koenig W, de Jager W, Meisinger C, Illig T, Martin S, Kolb H: Chemokines as risk factors for type 2 diabetes: results from the MONICA/KORA Augsburg study, 1984-2002. Diabetologia 2006, 49:921-929.

17. Niu J, Kolattukudy PE: Role of MCP-1 in cardiovascular disease: molecular mechanisms and clinical implications. Clin Sci (Lond) 2009, 117:95-109.

18. Aukrust P, Halvorsen B, Yndestad A, Ueland T, Oie E, Otterdal K, Gullestad L, Damas JK: Chemokines and cardiovascular risk. Arterioscler Thromb Vasc Biol 2008, 28:1909-1919.

19. van Oostrom AJ, Rabelink TJ, Verseyden C, Sijmonsma TP, Plokker HW, De Jaegere PP, Cabezas MC: Activation of leukocytes by postprandial lipemia in healthy volunteers. Atherosclerosis 2004, 177:175-182.

20. Alipour A, van Oostrom AJ, Izraeljan A, Verseyden C, Collins JM, Frayn KN, Plokker TW, Elte JW, Cabezas MC: Leukocyte Activation by TriglycerideRich Lipoproteins. Arterioscler Thromb Vasc Biol 2008.

21. Bouwens M, Grootte Bromhaar M, Jansen J, Muller M, Afman LA: Postprandial dietary lipid-specific effects on human peripheral blood mononuclear cell gene expression profiles. Am J Clin Nutr 2010, 91:208-217.

22. Huo Y, Schober A, Forlow SB, Smith DF, Hyman MC, Jung S, Littman DR, Weber $C$, Ley $K$ : Circulating activated platelets exacerbate atherosclerosis in mice deficient in apolipoprotein E. Nat Med 2003, 9:61-67.

23. Koenen RR, von Hundelshausen P, Nesmelova IV, Zernecke A, Liehn EA, Sarabi A, Kramp BK, Piccinini AM, Paludan SR, Kowalska MA, Kungl AJ, Hackeng TM, Mayo KH, Weber C: Disrupting functional interactions between platelet chemokines inhibits atherosclerosis in hyperlipidemic mice. Nat Med 2009, 15:97-103.

24. Veillard NR, Kwak B, Pelli G, Mulhaupt F, James RW, Proudfoot AE, Mach F: Antagonism of RANTES receptors reduces atherosclerotic plaque formation in mice. Circ Res 2004, 94:253-261.

25. Wu H, Ghosh S, Perrard XD, Feng L, Garcia GE, Perrard JL, Sweeney JF, Peterson LE, Chan L, Smith CW, Ballantyne CM: T-cell accumulation and regulated on activation, normal $\mathrm{T}$ cell expressed and secreted upregulation in adipose tissue in obesity. Circulation 2007, 115:1029-1038.

26. Galland L: Diet and inflammation. Nutr Clin Pract 2010, 25:634-640.

27. Amar J, Burcelin R, Ruidavets JB, Cani PD, Fauvel J, Alessi MC, Chamontin B, Ferrieres J: Energy intake is associated with endotoxemia in apparently healthy men. Am J Clin Nutr 2008, 87:1219-1223.

28. Heinonen MV, Laaksonen DE, Karhu T, Karhunen L, Laitinen T, Kainulainen S, Rissanen A, Niskanen L, Herzig KH: Effect of diet-induced weight loss on plasma apelin and cytokine levels in individuals with the metabolic syndrome. Nutr Metab Cardiovasc Dis 2009, 19:626-633.

29. van Dijk SJ, Feskens EJ, Bos MB, Hoelen DW, Heijligenberg R, Bromhaar MG, de Groot LC, de Vries JH, Muller M, Afman LA: A saturated fatty acid-rich diet induces an obesity-linked proinflammatory gene expression profile in adipose tissue of subjects at risk of metabolic syndrome. Am J Clin Nutr 2009, 90:1656-1664.

30. Rogowski O, Shapira I, Steinvil A, Berliner S: Low-grade inflammation in individuals with the hypertriglyceridemic waist phenotype: another feature of the atherogenic dysmetabolism. Metabolism 2009, 58:661-667.

31. Margioris AN: Fatty acids and postprandial inflammation. Curr Opin Clin Nutr Metab Care 2009, 12:129-137.

32. Jimenez-Gomez Y, Lopez-Miranda J, Blanco-Colio LM, Marin C, PerezMartinez P, Ruano J, Paniagua JA, Rodriguez F, Egido J, Perez-Jimenez F: Olive oil and walnut breakfasts reduce the postprandial inflammatory response in mononuclear cells compared with a butter breakfast in healthy men. Atherosclerosis 2009, 204:e70-6.

33. Myhrstad MC, Narverud I, Telle-Hansen VH, Karhu T, Bodtker Lund D, Herzig KH, Makinen M, Halvorsen B, Retterstol K, Kirkhus B, Granlund L, 
Holven KB, Ulven SM: Effect of the fat composition of a single high-fat meal on inflammatory markers in healthy young women. Br J Nutr 2011, $1-10$.

34. Huffman KM, Orenduff MC, Samsa GP, Houmard JA, Kraus WE, Bales CW: Dietary carbohydrate intake and high-sensitivity C-reactive protein in atrisk women and men. Am Heart J 2007, 154:962-968.

35. Arya F, Egger S, Colquhoun D, Sullivan D, Pal S, Egger G: Differences in postprandial inflammatory responses to a 'modern' $v$. traditional meat meal: a preliminary study. Br I Nutr 2010, 104:724-728

36. Zemel MB, Sun X, Sobhani T, Wilson B: Effects of dairy compared with soy on oxidative and inflammatory stress in overweight and obese subjects. Am J Clin Nutr 2010, 91:16-22.

37. Panagiotakos DB, Pitsavos CH, Zampelas AD, Chrysohoou CA, Stefanadis Cl: Dairy products consumption is associated with decreased levels of inflammatory markers related to cardiovascular disease in apparently healthy adults: the ATTICA study. J Am Coll Nutr 2010, 29:357-364.

38. Nilsson M, Stenberg M, Frid AH, Holst JJ, Bjorck IM: Glycemia and insulinemia in healthy subjects after lactose-equivalent meals of milk and other food proteins: the role of plasma amino acids and incretins. Am J Clin Nutr 2004, 80:1246-1253.

39. Pal $\mathrm{S}$, Ellis $\mathrm{V}, \mathrm{Ho} \mathrm{S}$ : Acute effects of whey protein isolate on cardiovascular risk factors in overweight, post-menopausal women. Atherosclerosis 2010, 212:339-344.

40. Mortensen LS, Hartvigsen ML, Brader L, Astrup A, Schrezenmeir J, Holst JJ, Thomsen C, Hermansen K: Differential effects of protein quality on postprandial lipemia in response to a fat-rich meal in type 2 diabetes: comparison of whey, casein, gluten, and cod protein. Am J Clin Nutr 2009, 90:41-48

41. Lehto SM, Niskanen L, Herzig KH, Tolmunen T, Huotari A, Viinamaki $H_{\text {, }}$ Koivumaa-Honkanen H, Honkalampi K, Ruotsalainen H, Hintikka J: Serum chemokine levels in major depressive disorder. Psychoneuroendocrinology 2010, 35:226-232.

42. Rabe-Hesketh S: Multilevel and longitudinal modeling using Stata Texas: Stata Press; 2008.

43. Alipour A, Elte JW, van Zaanen HC, Rietveld AP, Cabezas MC: Postprandial inflammation and endothelial dysfuction. Biochem Soc Trans 2007, 35:466-469.

44. Grewal IS, Rutledge BJ, Fiorillo JA, Gu L, Gladue RP, Flavell RA, Rollins BJ: Transgenic monocyte chemoattractant protein-1 (MCP-1) in pancreatic islets produces monocyte-rich insulitis without diabetes: abrogation by a second transgene expressing systemic MCP-1.J Immunol 1997, 159:401-408.

45. Krohn R, Raffetseder U, Bot I, Zernecke A, Shagdarsuren E, Liehn EA, van Santbrink PJ, Nelson PJ, Biessen EA, Mertens PR, Weber C: Y-box binding protein-1 controls CC chemokine ligand-5 (CCL5) expression in smooth muscle cells and contributes to neointima formation in atherosclerosisprone mice. Circulation 2007, 116:1812-1820.

46. Braunersreuther V, Steffens S, Arnaud C, Pelli G, Burger F, Proudfoot A, Mach F: A novel RANTES antagonist prevents progression of established atherosclerotic lesions in mice. Arterioscler Thromb Vasc Biol 2008, 28:1090-1096.

47. Braunersreuther V, Zernecke A, Arnaud C, Liehn EA, Steffens S, Shagdarsuren E, Bidzhekov K, Burger F, Pelli G, Luckow B, Mach F, Weber C: C $c r 5$ but not $\mathrm{Ccr} 1$ deficiency reduces development of diet-induced atherosclerosis in mice. Arterioscler Thromb Vasc Biol 2007, 27:373-379.

48. Breland UM, Michelsen AE, Skjelland M, Folkersen L, Krohg-Sorensen K Russell D, Ueland T, Yndestad A, Paulsson-Berne G, Damas JK, Oie E, Hansson GK, Halvorsen B, Aukrust P: Raised MCP-4 levels in symptomatic carotid atherosclerosis: an inflammatory link between platelet and monocyte activation. Cardiovasc Res 2010, 86:265-273.

49. Kraaijeveld AO, de Jager SC, de Jager WJ, Prakken BJ, McColl SR, Haspels I, Putter H, van Berkel TJ, Nagelkerken L, Jukema JW, Biessen EA: CC chemokine ligand-5 (CCL5/RANTES) and CC chemokine ligand-18 (CCL18/PARC) are specific markers of refractory unstable angina pectoris and are transiently raised during severe ischemic symptoms. Circulation 2007, 116:1931-1941.

50. Kobusiak-Prokopowicz M, Orzeszko J, Mazur G, Mysiak A, Orda A, Poreba R, Mazurek W: Chemokines and left ventricular function in patients with acute myocardial infarction. Eur J Intern Med 2007, 18:288-294.

51. Jones KL, Maguire JJ, Davenport AP: Chemokine receptor CCR5: from AIDS to atherosclerosis. Br J Pharmacol 2011, 162:1453-1469.
52. Bursill CA, Castro ML, Beattie DT, Nakhla S, van der Vorst E, Heather AK, Barter PJ, Rye KA: High-density lipoproteins suppress chemokines and chemokine receptors in vitro and in vivo. Arterioscler Thromb Vasc Biol 2010, 30:1773-1778.

53. Herder C, Peltonen M, Koenig W, Kraft I, Muller-Scholze S, Martin S, Lakka T, Ilanne-Parikka P, Eriksson JG, Hamalainen H, Keinanen-Kiukaanniemi S, Valle T, Uusitupa M, Lindstrom J, Kolb H, Tuomilehto J: Systemic immune mediators and lifestyle changes in the prevention of type 2 diabetes: results from the Finnish Diabetes Prevention Study. Diabetes 2006, 55:2340-2346.

54. De Caterina R, Massaro M: Omega-3 fatty acids and the regulation of expression of endothelial pro-atherogenic and pro-inflammatory genes. J Membr Biol 2005, 206:103-116.

55. Adkins Y, Kelley DS: Mechanisms underlying the cardioprotective effects of omega-3 polyunsaturated fatty acids. J Nutr Biochem 2010, 21:781-792

56. Clare DA, Swaisgood HE: Bioactive milk peptides: a prospectus. J Dairy SCi 2000, 83:1187-1195.

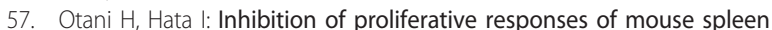
lymphocytes and rabbit Peyer's patch cells by bovine milk caseins and their digests. J Dairy Res 1995, 62:339-348.

58. Aihara K, Ishii H, Yoshida M: Casein-derived tripeptide, Val-Pro-Pro (VPP), modulates monocyte adhesion to vascular endothelium. J Atheroscler Thromb 2009, 16:594-603.

59. Vordenbaumen S, Braukmann A, Petermann K, Scharf A, Bleck E, von Mikecz A, Jose J, Schneider M: Casein alpha s1 is expressed by human monocytes and upregulates the production of GM-CSF via p38 MAPK. J Immunol 2011, 186:592-601.

60. Dandona P, Aljada A, Mohanty P, Ghanim H, Hamouda W, Assian E, Ahmad S: Insulin inhibits intranuclear nuclear factor kappaB and stimulates IkappaB in mononuclear cells in obese subjects: evidence for an anti-inflammatory effect? J Clin Endocrinol Metab 2001, 86:3257-3265.

61. Aljada A, Ghanim H, Saadeh R, Dandona P: Insulin inhibits NFkappaB and MCP-1 expression in human aortic endothelial cells. J Clin Endocrinol Metab 2001, 86:450-453.

62. Ghanim H, Korzeniewski K, Sia CL, Abuaysheh S, Lohano T, Chaudhuri A, Dandona P: Suppressive effect of insulin infusion on chemokines and chemokine receptors. Diabetes Care 2010, 33:1103-1108.

doi:10.1186/1475-2891-10-115

Cite this article as: Holmer-Jensen et al:: Differential effects of dietary protein sources on postprandial low-grade inflammation after a single high fat meal in obese non-diabetic subjects. Nutrition Journal 2011 10:115.

\section{Submit your next manuscript to BioMed Central and take full advantage of:}

- Convenient online submission

- Thorough peer review

- No space constraints or color figure charges

- Immediate publication on acceptance

- Inclusion in PubMed, CAS, Scopus and Google Scholar

- Research which is freely available for redistribution 